\title{
PERANAN EKOLOGI DUSUNG DAN NON DUSUNG DAN KONTRIBUSINYA PADA KONSERVASI LINGKUNGAN DI DESA URENG KECAMATAN LEIHITU KABUPATEN MALUKU TENGAH
}

\section{THE ECOLOGICAL STUDY OF DUSUNG AND NON DUSUNG, AND THE ROLE OF THE CONTRIBUTION TO ENVIRONMENTAL CONSERVATION IN URENG VILLAGE IN CENTRAL MOLUCCAS DISTRIC}

\author{
Napsiah Heluth, J Matinahoru, Fransina Latumahina \\ Program Studi Manajemen Hutan, Pascasarjana Universitas Pattimura Ambon \\ 1) Jl. Dr. Ir. M. Latumeten, Kampus PGSD-Ambon 57131 \\ Penulis korespondensi e-mail: navieheluth@gmail.com \\ \begin{tabular}{l|l} 
Diterima : 2 Desember 2017 & Disetujui : 15 Desember 2017
\end{tabular}
}

\section{Intisari}

Penelitian bertujuan mengetahui kondisi ekologi dusung dan non dusung dan peranan dusung kontribusinya terhadap konservasi lingkungan di Desa Ureng. Metode penelitian yang digunakan adalah purposive sampling dengan parameter pengamatan adalah iklim mikro (kadar $\mathrm{CO}_{2}$, suhu udara, kelembaban udara), kondisi vegetasi dan Kondisi tanah (Suhu tanah, kelembaban tanah, pH tanah, kadar air tanah, makrofauna tanah dan C-organik).

Hasil uji berpasangan dari setiap parameter yang diukur sebagian besar menunjukkan nilai t hitung yang lebih kecil dibandingkan dengan nilai $\mathrm{t}_{0,05}$ Tabel $(1,8595)$ yang berarti bahwa parameter tersebut tidak berbeda nyata yaitu untuk parameter kelembaban udara, $\mathrm{t}$ hitung $=-0,11 ; \mathrm{pH}$ tanah, $\mathrm{t}$ hitung $=$ 0,6 ; makrofauna tanah, $\mathrm{t}$ hitung $=-0,66$ dan vegetasi, $\mathrm{t}$ hitung $=1,01$. Sedangkan untuk parameter $\mathrm{CO}_{2}$, suhu udara, suhu tanah, kelembaban tanah, kadar air tanah dan C-organik, nilai t hitung $\mathrm{CO}_{2}=-$ 16,06; suhu udara $=-5,11$; suhu tanah $=-3,62$; kelembaban tanah,t hitung $=2,16$; kadar air tanah $=$ 8,47 , dan C-Organik $=8,53$; nilai thitung yang lebih besar dari nilai t Tabel yang menunjukkan bahwa ada beda yang nyata antara suhu udara, suhu tanah, kelembaban tanah, kadar air tanah dan COrganik pada areal dusun yang lebih besar dibanding pada areal non dusun. Dari hasil analisis diketahui bahwa dusung lebih baik perannya dalam konservasi lingkungan jika dibandingkan dengan non dusung yang ditunjukkan oleh nilai suhu udara, suhu tanah, kadar air tanah dan kandungan Corganik.

Kata Kunci : dusung, non dusung, manajemen ekologi

\begin{abstract}
The research study aims to determine the ecological conditions of dusung and non dusung, and the role of the contribution to environmental conservation in Ureng Village. The research method used was purposive sampling with observation parameters were microclimate $\left(\mathrm{CO}_{2}\right.$ content, air temperature, humidity), vegetation conditions and soil conditions (soil temperature, soil moisture, soil $\mathrm{pH}$, soil moisture content, soil macrofauna and organic C) . The results of Paired of each parameter measured mostly show a smaller calculated $t$ value compared to the $t_{0.05}$ table value $(1.8595)$ which means that the parameter is not a real difference, ie for the air humidity, $\mathrm{t}$ count $=0.27$; soil $\mathrm{pH}, \mathrm{t}$ count $=0.6$; soil macrofauna, $\mathrm{t}$ count $=-0.66$ and vegetation, $\mathrm{t}$ count $=1.01$. As for the parameters of $\mathrm{CO}_{2}$; air temperature, soil temperature, , soil water content and organic $\mathrm{C}$, $\mathrm{t}$ value of $\mathrm{CO}_{2}$ gives the value $\mathrm{t}$ count $=-16.06$; air temperature $=-5.11$; soil temperature $=-3.62$; soil moisture, $\mathrm{t}$ count $=2,16$; soil water content $=8.47$, and $\mathrm{C}$-Organic $=8.53$; $\mathrm{t}$ count value which is greater than $\mathrm{t}$ table value which shows that there is a significant difference between $\mathrm{CO}_{2}$, air temperature, soil temperature, soil moisture, soil water content and C-Organic content in the dusung area which is greater than in the non-dusung area. From the results of the analysis it is known that dusung has a better role in environmental conservation when compared to non dusung which is indicated by the value of $\mathrm{CO}_{2}$ air temperature, soil temperature, soil moisture, soil water content and C-organic content.
\end{abstract}

Keywords: Dusung, Non Dusung, Ecological Measurement 


\section{PENDAHULUAN}

Tekanan yang besar terhadap sumber daya alam akibat aktivitas manusia ditunjukkan dengan perubahan tutupan lahan yang meningkat dan kebutuhan pokok mengakibatkan kebutuhan penduduk akan areal pertanian yang lebih luas dan diusahakan lebih intensif. Berdasarkan hal ini maka diperlukan kegiatan pengelolaan lahan yang optimal untuk mendapatkan hasil yang maksimal guna memenuhi kebutuhan masyarakat.

Salah satu sistem usaha tani yang mampu memperkecil kendala pengembangan pertanian di lahan kering adalah dengan sistem agroforestri. Agroforestri merupakan sistem dan teknologi penggunaan lahan yang mengkombinasikan produksi tanaman pertanian dan kehutanan pada unit lahan yang sama (Hairiah et all, 2003).

Sistim agroforestri tradisional di Maluku yakni dusung merupakan sistem pemanfaatan lahan berkelanjutan yang memiliki nilai manfaat yang tinggi pada saat ini dan masa yang akan datang (Hatulesilla, 2009). Tanaman tahunan dalam dusung adalah Cengkeh (Eugenia aromatica), Pala (Myristica fragrans), Sagu (Metroxilon sagu), Kelapa (Cocus nucifera), Kakao (Theobroma cacao, dan pohon buahbuahan. Tanaman pertanian berumur pendek didominasi adalah Ubi kayu (Manihot utilisima), Ubi jalar (Ipomea batatas),
Jagung (Zea mays), Kacang-kacangan dan sayuran. Dusung bermanfaat sebagai sumber makanan, menghasilkan uang tunai, meningkatkan pendapatan rumah tangga, dan melestarikan ekosistem. Sempitnya pemahaman masyarakat mengenai manfaat dusung secara ekonomis maupun ekologis, mengakibatkan apresiasi/penghargaan masyarakat terhadap manfaat dusun sangat sempit, hanya manfaat ekonomi, sedangkan pemanfaatan jasa ekologi dianggap tidak bernilai (public goods), sehingga diabaikan dalam menghitung kontribusi nilai ekonomi. Keadaan ini berimplikasi terhadap miskonsepsi mengenai rendahnya nilai ekonomi sistem agroforestri dibandingkan bentuk pemanfaatan lahan lainnya, dusung dianggap sebagai bank petani di beberapa pulau yang terisolasi (Matinahoru, 2014).

Non Dusung adalah areal kebun atau bekas kebun yang tidak diklaim petani sebagai dusung dan kondisi lahan terbuka, terdiri semak belukar, atau usaha kebun yang bersifat sementara.

Sistem agroforestri dusung di Desa Ureng memadukan tanaman tahunan (buah dan kayu) dengan tanaman semusim (buah dan sayuran, dan pangan) sangat bermanfaat bagi kehidupan masyarakat dari segi ekonomi dan ekologi.

Informasi dan data kuantitatif mengenai sistem agroforestri dusung di Desa Ureng tidak tersedia sehingga penilaian yang 
dilakukan lebih bersifat subjektif dan kualitatif, sehingga perlu dilakukan perhitungan terhadap nilai ekologi agroforestri yang meliputi iklim mikro, kondisi mikroklimat tanah, vegetasi, makrofauna tanah dan C-Organik. Berdasarkan latar belakang tersebut maka

\section{METODE PENELITIAN}

\section{Lokasi dan Waktu Penelitian}

Penelitian dilaksanakan di Desa Ureng dan penelitian laboratorium pada Balai Pengkajian Teknologi Pertanian Sulawesi Selatan dan Laboratorium Silvikultur Fakultas Pertanian Universitas Pattimura Ambon, yang berlangsung pada bulan Oktober 2016 - Oktober 2017.

\section{Alat dan Bahan}

Alat yang digunakan yakni: $\mathrm{CO}_{2}$ meter Geotech G150, thermometer, pH-

\section{Metode Pengumpulan Data}

Penelitian menggunakan metode purposive sampling dengan parameter pengamatan adalah iklim mikro $\left(\right.$ kadar $\mathrm{CO}_{2}$, suhu udara, kelembaban udara), kondisi vegetasi dan Kondisi tanah (Suhu tanah, kelembaban tanah, $\mathrm{pH}$ tanah, kadar air tanah, makrofauna tanah dan C-organik). Inventarisasi vegetasi dilakukan pada petak berukuran $20 \mathrm{~m}$ x $20 \mathrm{~m}$ untuk pohon, $10 \mathrm{~m}$ $\mathrm{x} 10 \mathrm{~m}$ untuk tiang, $5 \mathrm{~m} \times 5 \mathrm{~m}$ untuk pancang dan $2 \mathrm{~m}$ x $2 \mathrm{~m}$ untuk semai.

Data diambil pada plot berukuran 100 m x 100 m (1 Ha). Pengukuran $\mathrm{CO}_{2}$ akan dicapai dari penelitian yakni mengetahui kondisi ekologi pola dusung dan non dusung di Desa Ureng dan mengetahui peranan dusung dan non dusung terhadap konservasi lingkungan di Desa Ureng.

meter, higrometer, Soil tester, timbangan, oven, botol koleksi, kantong tanah, pinset, nampan plastik, parang, cawan petri, meter roll, tali rafia, kertas label, kamera digital, tally sheet, patok kayu, sekop kecil, karet gelang, kapas, kuas hitam kecil, alat tulis, papan oles, GPS, seperangkat PC (personal computer) dengan perangkat lunak (software) Microsoft Office (MS. Office dan MS. Excel), dan Minitab 14. Bahan yang digunakan yakni alkohol 70\%, tanah dan makrofauna tanah.

menggunakan $\mathrm{CO}_{2}$ meter, suhu udara menggunakan thermometer dan kelembaban udara menggunakan Higrometer. Pengukuran suhu tanah dilakukan pada kedalaman tanah $10 \mathrm{~cm}$ dari permukaan tanah menggunakan thermometer pada plot ukuran $1 \mathrm{~m}$ x $1 \mathrm{~m}$. Pengukuran kelembaban tanah dilakukan pada kedalaman tanah 10 $\mathrm{cm}$ dari permukaan tanah menggunakan Soil tester.

Pengambilan makrofauna tanah menggunakan metode hand collecting (pengumpulan menggunakan tangan) dan dimasukkan dalam botol koleksi berisi 
alkohol $70 \%$ yang diberi label. Inventarisasi vegetasi menggunakan metode jalur dengan ukuran panjang jalur $100 \mathrm{~m}$, lebar jalur $20 \mathrm{~m}$ dan jarak antar jalur $20 \mathrm{~m}$..

\section{Analisis Data}

Analisis statistik yang digunakan untuk membedakan atau membandingkan hasil pengukuran antara dusung dan non dusung adalah uji $\mathrm{t}(\mathrm{t}$ test) dengan rumus :

$\mathrm{t}_{\text {hitung }}=\frac{\left(\bar{X}_{A}-\bar{X}_{B}\right)-\left(\mu_{A}-\mu_{B}\right)}{s_{g a b} \sqrt{\frac{1}{n_{A}}+\frac{1}{n_{B}}}}$

Dengan asumsi :

1. Bila $\sigma_{A}^{2}$ dan $\sigma_{B}^{2}$ tidak diketahui

2.

$$
\sigma_{A}^{2}=\sigma_{B}^{2}
$$

\section{HASIL DAN PEMBAHASAN}

\section{Kadar $\mathrm{CO}_{2}$}

Hasil pengukuran $\mathrm{CO}_{2}$ pada dusung dan non dusung di Desa Ureng memberikan hasil yang berbeda, dimana pada dusung rata-rata jumlah $\mathrm{CO}_{2}$ di udara adalah sebesar 468,72 ppm, non dusung memiliki rata-rata jumlah $\mathrm{CO}_{2}$ di udara sebesar 474,91 ppm. Hasil ini menunjukkan bahwa pada dusung dengan kerapatan tanaman yang lebih besar menyerap $\mathrm{CO}_{2}$ lebih banyak jika dibandingkan dengan non dusung. Hal ini dipengaruhi oleh kondisi iklim mikro dan kerapatan tajuk pada tiap lokasi serta komposisi vegetasi dalam areal penelitian.

Berdasarkan Tabel 1, diketahui bahwa kadar $\mathrm{CO}_{2}$ di dusung maupun non dusung mengalami perubahan pada setiap waktu pengamatan. Pada areal dusung nilai rata-rata $\mathrm{CO}_{2}$ tertinggi terjadi pada saat pagi hari (07.00-10.00 WIT) yaitu sebesar 521,89 ppm.

Tabel 1. Hasil Pengukuran Kadar $\mathrm{CO}_{2}$, Suhu Udara dan Kelembaban Udara pada Llokasi Penelitian

\begin{tabular}{|l|l|c|c|c|c|}
\hline \multirow{2}{*}{$\begin{array}{l}\text { Waktu Pengukuran } \\
\text { (WIT) }\end{array}$} & $\begin{array}{l}\text { Penggunaan } \\
\text { Lahan }\end{array}$ & \multicolumn{3}{|c|}{$\mathrm{CO}_{2}(\mathrm{ppm})$} & \multirow{2}{*}{ RRata-rata } \\
\cline { 2 - 5 } Pagi (07.00-10.00) & Jalur I & Jalur II & Jalur III & \\
\cline { 2 - 5 } & Non Dusung & 508,83 & 512,67 & 544,17 & 521,89 \\
\hline \multirow{2}{*}{ Siang(12.00-15.00) } & Dusung & 417,33 & 565 & 478,33 & 529,55 \\
\cline { 2 - 5 } & Non Dusung & 482,83 & 465,67 & 520,5 & 468,00 \\
\hline \multirow{2}{*}{ Sore (17.00-18.00) } & Dusung & 390,83 & 423,17 & 458,5 & 483,11 \\
\cline { 2 - 5 } & Non Dusung & 412,67 & 402,67 & 420,83 & 416,28 \\
\hline & Dusung & 439,16 & 467,17 & 499,83 & 412,06 \\
\cline { 2 - 5 } & Non Dusung & 480,28 & 491,89 & 452,55 & 474,91 \\
\hline
\end{tabular}

Pada siang siang hari (12.00-15.00 WIT) jumlah $\mathrm{CO}_{2}$ ini turun 53,89 ppm sebab waktu ini merupakan salah satu waktu puncak fotosintesis dimana tanaman menyerap $\mathrm{CO}_{2}$ dan sore hari (17.00-18.00 WIT) turun 51,72 ppm menjadi 416,28 ppm. Pada areal non dusung nilai rata-rata $\mathrm{CO}_{2}$ tertinggi juga terjadi pada saat pagi hari (07.00-10.00 WIT) yaitu sebesar 529,55 ppm. Pada siang siang hari (12.00-15.00 WIT) jumlah $\mathrm{CO}_{2}$ ini turun 46.44 ppm dan juga pada sore hari juga turun $71,05 \mathrm{ppm}$ menjadi 412,06 ppm. 


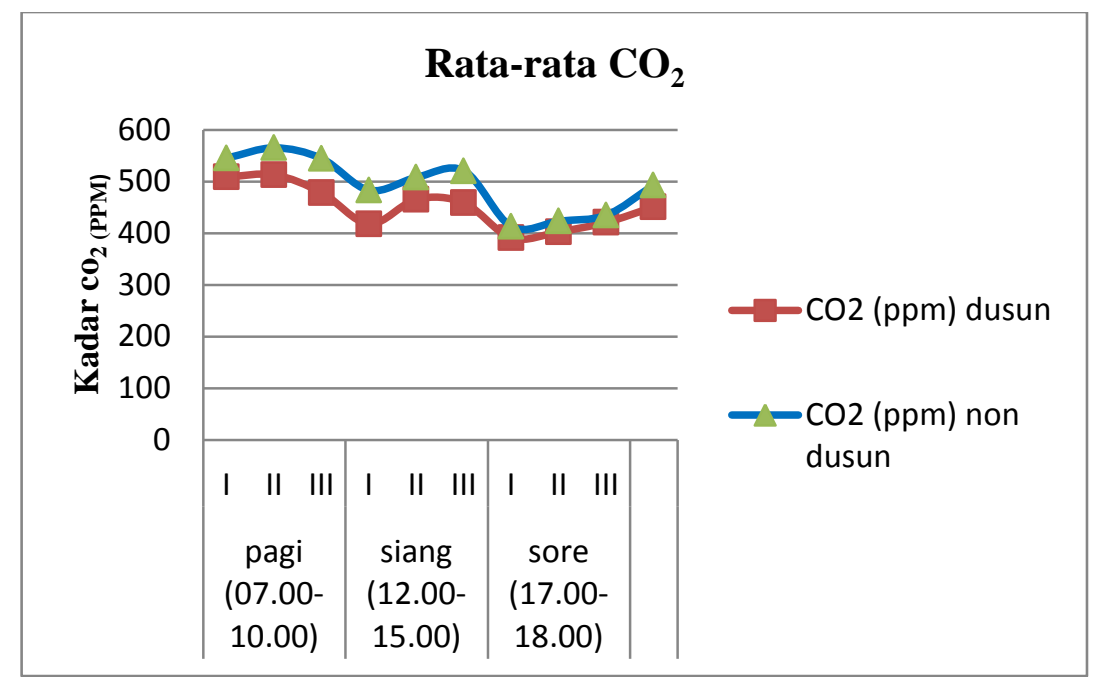

Gambar 1. Rata-rata Kadar $\mathrm{CO}^{2}$ Dusung dan Non Dusung

Penebangan vegetasi dalam kawasan dusung dan non dusung dapat mengurangi penyerapan karbon oleh pohon. Hal ini sejalan dengan penelitian Raha (2011) yang menyatakan bahwa penggundulan hutan dapat mengurangi penyerapan karbon oleh pohon, emisi karbon meningkat sebesar $20 \%$, dan mengubah iklim mikro dan siklus hidrologis. $\mathrm{CO} 2$ merupakan salah satu gas rumah kaca yang memberikan efek terhadap pemanasan global dan perubahan iklim. Gas rumah kaca menyebabkan energi panas yang berupa gelombang panjang terperangkap di dalam atmosfer bumi sehingga menimbulakan efek pemanasan global. Gasgas Rumah Kaca (GRK) dihasilkan dari berbagai kegiatan manusia, seperti kegiatan industri, transportasi, kebakaran hutan, perubahan tata guna lahan, pertanian, peternakan, sampah dan sebagainya (Bulan,2010).

\section{Suhu Udara}

Pengukuran suhu udara pada masingmasing areal menunjukan perbedaan dimana suhu udara pada areal pada dusung sebesar $28,56{ }^{\circ} \mathrm{C}$ dan non dusung sebesar $29,52^{\circ} \mathrm{C}$. Suhu udara berfluktuasi pada setiap perubahan waktu pada masing-masing dusung. Perubahan ini jelas terlihat dimana suhu udara cenderung naik pada siang hari dan turun pada sore hari menjelang malam hari.

Suhu udara terendah pada dusung sebesar $26^{\circ} \mathrm{C}$ pada pukul $07.00-10.00$ WIT dan tertinggi sebesar $32^{\circ} \mathrm{C}$ di siang hari pada pukul 12.00 -15.00 WIT. Sedangkan pada non dusung, suhu terendah adalah $26^{\circ} \mathrm{C}$ pada pukul 07.00 -10.00 WIT dan tertinggi adalah $32^{\circ} \mathrm{C}$ di siang hari pada pukul $12.00-15.00$ WIT dan juga pada sore hari pada pukul $17.00-18.00$

WIT. 


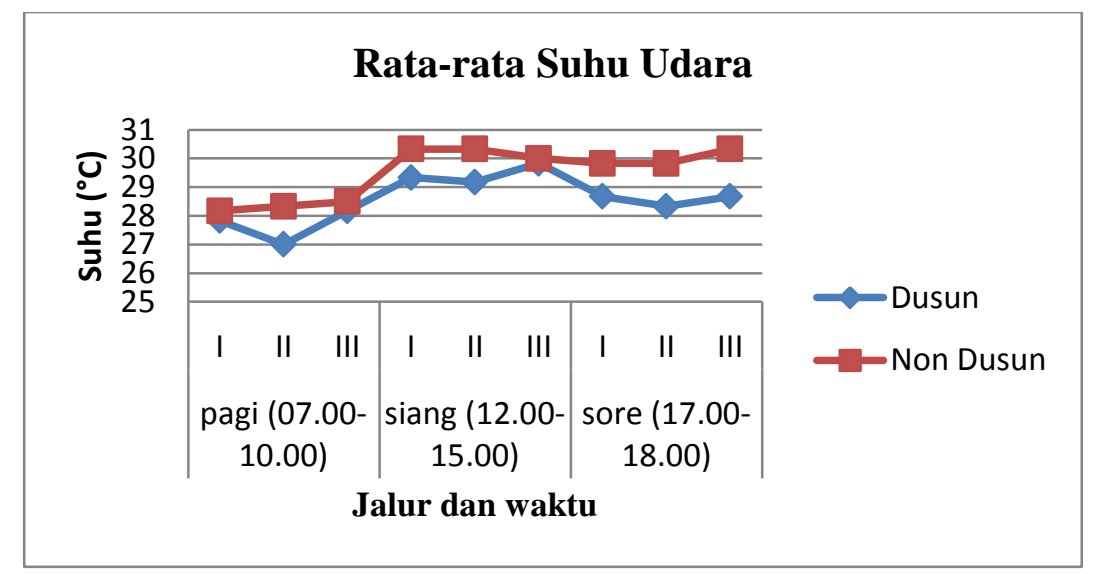

Gambar 2. Rata-rata Suhu Udara Dusung dan Non Dusung

Suhu udara berkaitan dengan penyinaran matahari yang menembus hingga lantai hutan. Persentase tutupan kanopi yang tinggi dapat mengurangi intensitas penyinaran matahari hingga lantai hutan, akibatnya suhu udara akan menurun dan menaikan kelembaban udara (Latumahina,2016).

Tutupan kanopi dusung lebih tertutup dan rapat dibandingkan dengan areal non dusung yang lebih terbuka. Hasil analisis menunjukkan suhu berkorelasi positif terhadap kerapatan vegetasi. Pada dusung terlihat korelasi yang cukup kuat ( $\mathrm{r} 2=0.43$, $\mathrm{p}>0.05$ ), dengan nilai korelasi positif sebesar 0,66; dan non dusung memperlihatkan korelasi yang kuat $\left(\mathrm{r}^{2}=0.93, \mathrm{p}>0,05\right)$ dengan nilai korelasi positif sebesar 0,97. Pada area yang terbuka tanpa vegetasi mempunyai suhu yang tinggi dan kelembaban yang rendah, hal ini disebabkan pada area terbangun dan area terbuka terkena radiasi matahari secara langsung dan segera memanaskan permukaan bangunan, perkerasan dan selanjutnya memanaskan suhu udara di atasnya, (Saputro, 2010).

\section{Kelembaban Udara}

Hasil pengukuran di lapangan menunjukkan kelembaban udara pada areal dusung sebesar $81,18 \%$ dan non dusung sebesar $80,31 \%$. Hal ini disebabkan karena tutupan vegetasi pada dusung lebih rapat sehingga sinar matahari tertahan oleh tajuk dan menyebabkan kondisi kelembaban pada dusung menjadi lebih tinggi. 


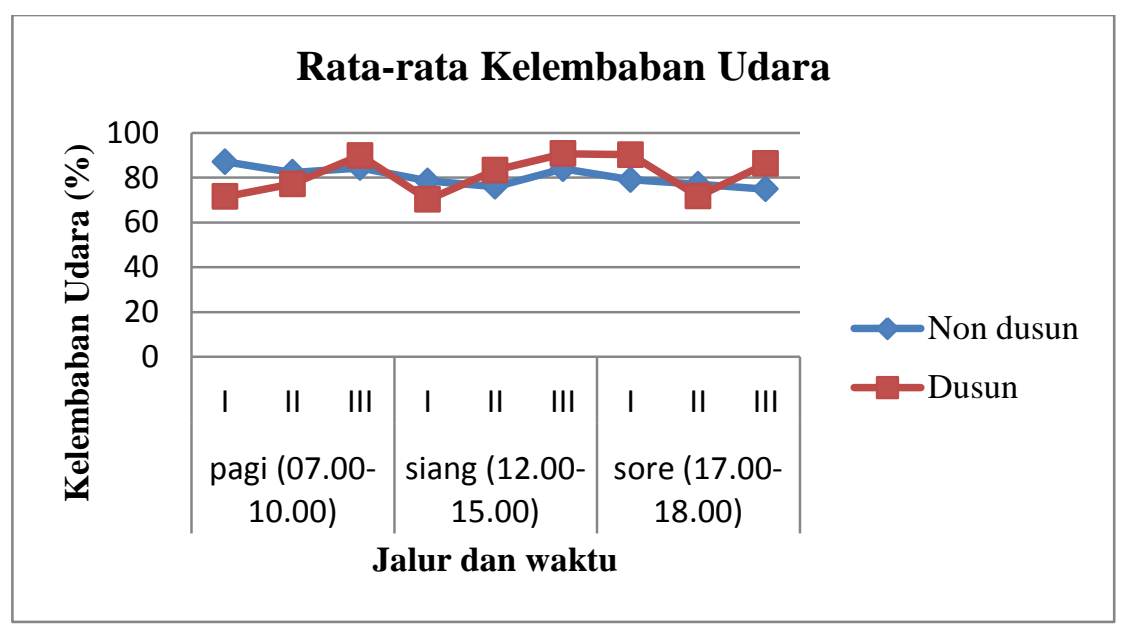

Gambar 3. Rata-rata Kelembaban Udara Dusung dan Non Dusung

Persentase tutupan kanopi yang tinggi akan menurunkan suhu udara dan menaikan kelembaban udara. Perbedaan kelembaban udara diduga disebabkan oleh perbedaan suhu udara, intensitas penyinaran matahari, kerapatan vegetasi dan tutupan kanopi. Hal ini sejalan dengan pendapat bahwa tinggi rendahnya kelembaban udara dalam kawasan hutan dipengaruhi oleh faktor ketersediaan air (air, tanah, perairan), tekanan udara, pergerakan angin, kuantitas dan kualitas penyinaran matahari (Latumahina,2016).

Pohon dengan tajuk yang rimbun, dan lebar memberikan bayangan luas, dimana jumlah daun dapat mengurangi sinar matahari langsung ke permukaan tanah. Tajuk dapat mengurangi efek radiasi matahari, karena tajuk pohon dapat memantulkan, meneruskan, dan menyerap radiasi matahari (Grey dan Denekke 1978 dalam Budiarti,2017).

Selain itu dengan proses transpirasi, tanaman menyerap panas dan mengeluarkan uap air yang dapat menurunkan suhu disekitarnya dan menaikkan kelembaban (Lakitan, 1997 dalam Budiarti, 2017).

\section{Suhu Tanah}

Hasil pengukuran suhu tanah, diketahui rata-rata suhu tanah tertinggi pada areal dusung sebesar $27,25^{\circ} \mathrm{C}$ dan terendah $25^{\circ} \mathrm{C}$ dan non dusung suhu tanah tertinggi sebesar $27,67^{\circ} \mathrm{C}$ dan terendah $25,92^{\circ} \mathrm{C}$.

Pada areal dusung rata-rata suhu tanah yang terukur lebih kecil dibandingkan non dusung. Pada areal dusung energi panas yang dipancarkan matahari terlebih dahulu diserap oleh tanaman untuk kegiatan transpirasi, sehingga panas yang diterima permukaan tanah berkurang. Pada non dusung energi panas matahari langsung diserap permukaan tanah.

Irawan (2009) menyatakan kanopi tertutup, suhu tanah rata-rata dan suhu permukaan tanah lebih kecil dibandingkan kanopi menengah dan kanopi terbuka, 
karena kanopi tertutup memiliki energi panas yang dipancarkan matahari terlebih dahulu diserap oleh tanaman untuk transpirasi, sehingga panas yang diterima berkurang. Sebaliknya, pada kanopi sedang dan kanopi terbuka, energi panas dari matahari dapat langsung diserap oleh permukaan tanah.

Tabel 2. Rata-rata Suhu Tanah dan Kelembaban Tanah pada Areal Dusung dan Non Dusung

\begin{tabular}{clcc}
$\begin{array}{c}\text { Waktu } \\
\text { Pengukuran } \\
\text { (WIT) }\end{array}$ & \multicolumn{1}{c}{$\begin{array}{c}\text { Pengelolaan } \\
\text { lahan }\end{array}$} & \multicolumn{2}{c}{ Rata-rata } \\
pagi $(07.00-10.00)$ & Dusung & $\begin{array}{c}\text { Tanah }\left({ }^{\circ} \mathbf{C}\right) \\
\text { Kelembaban } \\
\text { Tanah }(\%)\end{array}$ \\
\hline & Non Dusung & 25,61 & 83,72 \\
\hline siang (12.00-15.00) & Dusung & 26,39 & 79,72 \\
\hline & Non Dusung & 27,45 & 81,12 \\
\hline sore $(17.00-18.00)$ & Dusung & 26,39 & 81,5 \\
\hline & Non Dusung & 26,97 & 85,5 \\
\hline & Dusung & 26,26 & 69 \\
\hline & Non Dusung & 26,94 & 76,74 \\
\hline
\end{tabular}

Variasi suhu tanah harian menurut kedalaman ditentukan oleh kondisi cuaca dan variasi penerimaan radiasi surya. Panas yang diterima oleh permukaan tanah akan diteruskan pada lapisan tanah yang lebih dalam melalui proses konduksi. Panas yang dijalarkan akan memerlukan waktu, akibatnya suhu maksimum dan minimum di dalam tanah akan mengalami keterlambatan (Tjasyono B, 2006).

Sistem agroforestri memiliki kanopi yang menutupi sebagian atau seluruh permukaan tanah sehingga terbentuk seresah di permukaan tanah dan tanah lebih lembab, (Widianto $d k k$, 2003).



Gambar 4. Rata-rata Suhu Tanah Dusung dan Non Dusung 
Perbedaan suhu tanah berkaitan dengan jumlah panas yang sampai ke permukaan bumi akibat proses konduksi bumi (Sukarman \& Tafakresnanto, 1992) dalam Latumahina (2016). Sukarman \& Tafakresnanto (1992) bahwa nilai fluktuasi suhu tanah tergantung pada cuaca, intensitas cahaya matahari, topografi daerah dan jenis tanah. Suhu tanah pada areal dengan kanopi tertutup lebih rendah dibandingkan suhu tanah pada areal kanopi terbuka. Suhu tanah sangat menentukan kehadiran dan kepadatan organisme tanah, dan tingkat dekomposisi material organik tanah. Kanopi yang tertutup rapat menyulitkan cahaya matahari menembus hingga lantai hutan sehingga suhu tanah akan menurun (Latumahina, 2016).

\section{Kelembaban Tanah}

Berdasarkan hasil pengukuran, kelembaban tanah tertinggi pada areal dusung sebesar $82,27 \%$ saat pagi hari dan terendah adalah sebesar $76,67 \%$ saat siang hari dengan rata-rata kelembaban adalah sebesar $79,40 \%$.Sedangkan pada non dusung, kelembaban tanah tertinggi adalah sebesar $81,25 \%$ saat pagi hari dan terendah pada sore hari yaitu sebesar $70,50 \%$ saat sore hari dengan rata-rata sebesar 75,47\%.

Kelembaban tanah berfluktuasi sangat kecil dan cenderung konstan terhadap perubahan waktu pada masingmasing dusung. Kelembaban tanah pada areal dusung lebih tinggi, hal ini disebabkan kondisi tanah pada dusung lebih lembab, karena pada saat terjadi hujan sehingga kelembaban tanah meningkat.

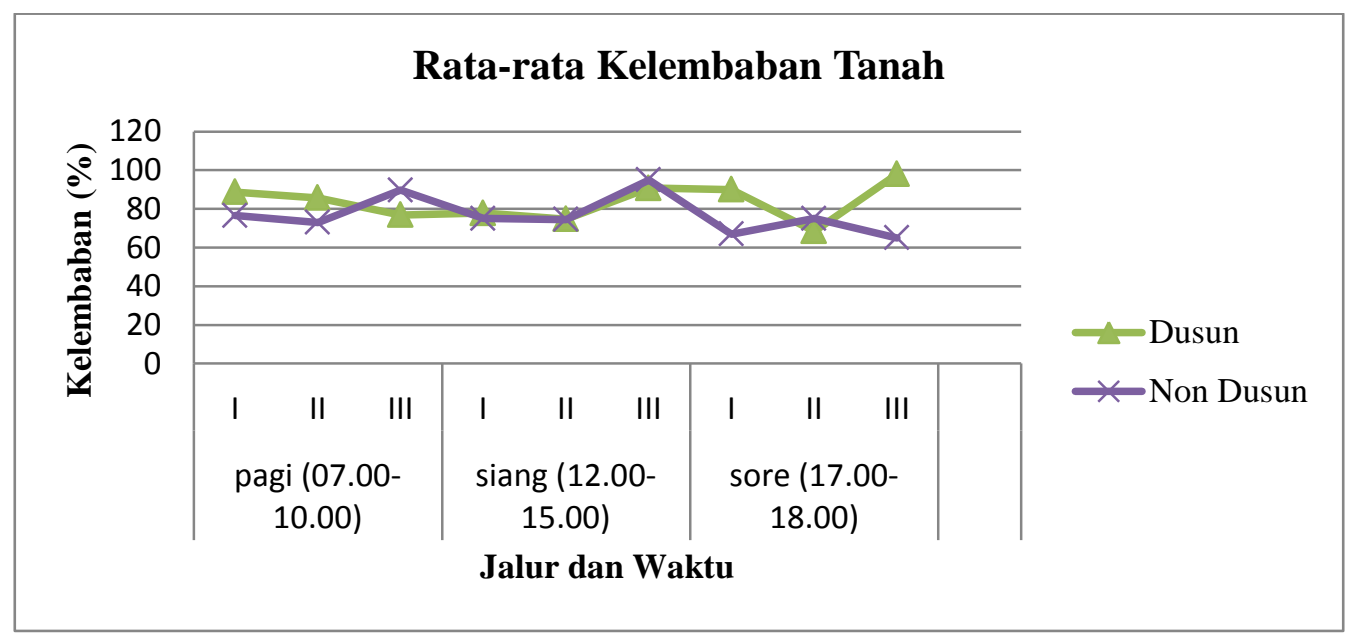

Gambar 5. Rata-rata Kelembaban Tanah Dusung dan Non Dusung

Kelembaban tanah pada kanopi tertutup lebih tinggi dibandingkan kelembaban tanah pada kanopi menengah dan terbuka. Hal ini disebabkan kondisi tanah pada kanopi tertutup lebih lembab dibandingkan kanopi menengah dan 
kanopi terbuka. Pada saat pengukuran, terjadi hujan yang mengakibatkan kelembaban tanah meningkat pada kanopi terbuka dan kanopi menengah (Irawan, 2009).

Pohon dapat menyejukkan lingkungan secara aktif dengan evaporasi dan

transpirasi (evapotranspirasi) dan secara pasif dengan melindungi permukaan dengan menaungi area di bawahnya yang dapat mengurangi gelombang pendek dari radiasi matahari (Kleerekoper dkk 2011 dalam Sanger, dkk 2016).

pH Tanah

Hasil pengukuran $\mathrm{pH}$ tanah menunjukkan hasil yang tidak berbeda antara dusung dan non dusung. Kondisi daerah penelitian yang masih berada dalam satu bentangan lahan dengan jenis tanah yang sama memberikan nilai $\mathrm{pH}$ sama.

Tabel 3. Hasil pengukuran pH tanah pada Areal Dusung dan Non Dusung

\begin{tabular}{cccccc}
\hline \multirow{2}{*}{ No. } & Penggunaan & \multicolumn{3}{c}{ pH Tanah } & \multirow{2}{*}{ Rata-rata } \\
\cline { 3 - 5 } & Lahan & Jalur I & Jalur II & Jalur III & \\
\hline 1. & Dusung & 4,23 & 4,38 & 3,85 & 4,15 \\
2. & Non Dusung & 3,83 & 4,05 & 4,17 & 4,02 \\
\hline
\end{tabular}

Tingkat kemasaman maupun kebasaan tanah ditunjukkan oleh nilai $\mathrm{pH}$. Hasil penelitian menunjukkan rata-rata nilai $\mathrm{pH}$ dusung maupun non dusung yakni 4,15 dan 4,02.
Di Indonesia umumnya tanahnya bereaksi masam dengan $\mathrm{pH} 3.0$-5.5 sehingga tanah dengan $\mathrm{pH} \quad 6.0-6.5$ bersifat netral meskipun masih agak masam, dan $\mathrm{pH}<$ 3.0 sangat masam (Hardjowigeno,2010 dalam Juliansah, 2016).

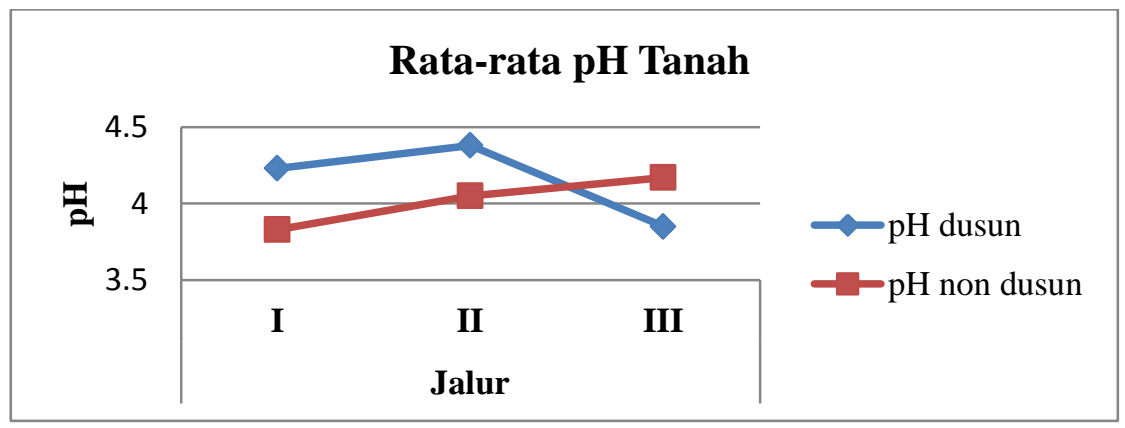

Gambar 6. Rata-rata pH tanah Dusung dan Non Dusung dimana batuan dikelompokkan menjadi induk berupa batuan dan bahan organik, batuan beku, sedimen dan metamorfose. 
Batuan basa umumnya mempunyai $\mathrm{pH}$ tinggi dibandingkan dengan tanah yang berkembang dari batuan masam. Tanah yang berada di bawah kondisi vegetasi hutan akan cenderung lebih masam dibandingkan dengan yang berkembang di bawah padang rumput. Hutan tanaman dengan daun kecil (konifer) menyebabkan tanah lebih masam dibandingkan dengan hutan tanaman berdaun lebar (Ardhana, 2012 dalam Khasanah, 2014).

\section{Kadar Air Tanah}

Kadar air tanah berdasarkan hasil pengukuran menunjukkan bahwa dusung memiliki kadar air yang lebih tinggi jika dibandingkan dengan areal non dusung.

Tabel 4. Rata-rata Kadar Air Tanah pada Areal Dusung dan Non Dusung

\begin{tabular}{cccccc}
\hline \multirow{2}{*}{ No. } & Penggunaan & \multicolumn{3}{c}{ Kadar Air Tanah (\%) } & \\
\cline { 3 - 4 } & lahan & Jalur I & Jalur II & Jalur III & rata-rata \\
\hline 1 & Dusung & 44,65 & 43,78 & 44,39 & 44,273 \\
2 & Non Dusung & 30,91 & 34,71 & 32,92 & 32,847 \\
\hline
\end{tabular}

Kadar air tanah dipengaruhi oleh kondisi vegetasi penyusun dan kondisi iklim mikro, dimana. penutupan tajuk yang lebih rapat pada dusung menyebabkan sinar matahari tidak langsung menyentuh permukaan tanah sehingga proses kehilangan air berjalan lebih lambat dan areal non dusung dengan tingkat penutupan tajuk yang rendah mempercepat proses kehilangan air.
Lapisan tanah atas adalah bagian yang paling cepat dan mudah terpengaruh oleh berbagai perubahan dan perlakuan. Kegiatan selama berlangsungnya proses alih-guna lahan segera mempengaruhi kondisi permukaan tanah. Penebangan hutan atau pepohonan mengakibatkan permukaan tanah menjadi terbuka, sehingga terkena sinar matahari dan pukulan air hujan secara langsung (Widianto dkk, 2003).

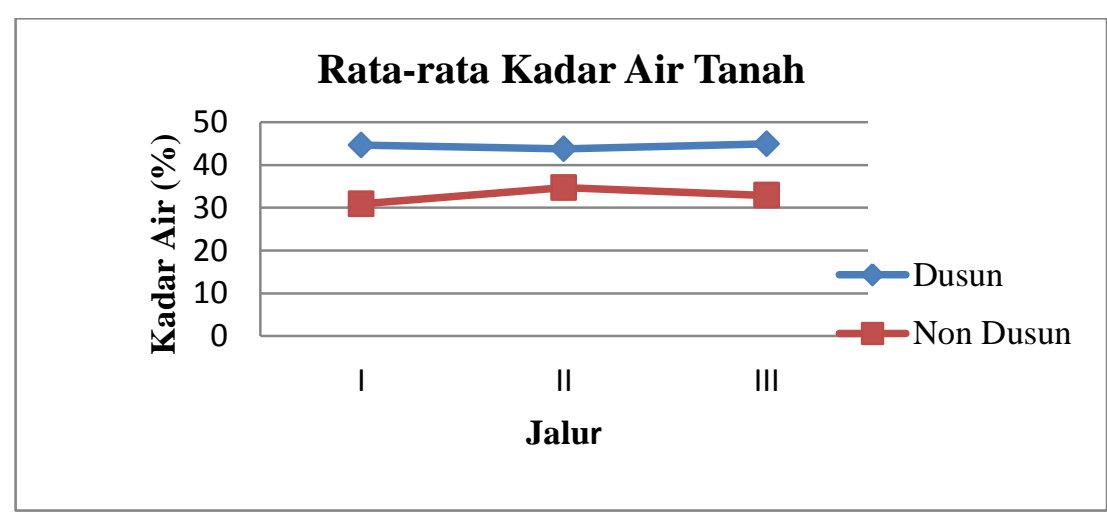

Gambar 7. Rata-Rata Kadar Air Tanah Dusung dan Non Dusung 
Widianto (2003), mengatakan hutan yang terdiri dari campuran pohon dan semak membentuk tajuk berlapis sehingga terjadi surplus arus air tahunan dalam tanah. Kondisi tanah di bawah tegakan mempunyai porositas dan kecepatan infiltrasi yang besar sehingga mendorong terjadinya aliran air pada

\section{Makrofauna Tanah}

Berdasarkan Tabel di atas, diketahui jumlah individu makrofauna tanah pada areal non dusung lebih banyak (13 jenis) dibandingkan dusung (11 jenis). Hasil penelitian Isbeanny (2014), bahwa jumlah makrofauna tanah di daerah non vegetasi justru lebih banyak dibandingkan jumlah makrofauna tanah yang didapatkan di daerah vegetasi. Hal ini mungkin disebabkan karena di permukaan tanah daerah non vegetasi banyak terdapat makrofauna tanah yang hanya sesaat keberadaannya (exotic) sehingga jumlah lapisan tanah lebih dalam maupun aliran horisontal.

Sistem agroforestri dapat mempertahankan sifat fisik lapisan tanah melalui seresah yang dapat menambah bahan organik tanah, kegiatan biologi tanah dan perakaran dan mempertahankan dan meningkatkan ketersediaan air dalam lapisan perakaran (Widianto $\mathrm{dk}, 2003$ ).

makrofauna tanah yang tertangkap lebih banyak di daerah non vegetasi daripada di daerah vegetasi.

Distribusi bahan organik dalam tanah berpengaruh terhadap cacing tanah, karena pada tanah miskin bahan organik hanya sedikit jumlah cacing tanah yang dijumpai (Hanafiah, 2015). Perbedaan jumlah jenis fauna tanah pada berbagai kondisi lahan disebabkan oleh keragaman jenis dan tumbuhan penutup tanah, sifat fisik dan kimia tanah (Latifah, 2012 dalam Isbeanny, 2012). 
Tabel 5. Makrofauna Tanah pada Areal Dusung dan Non Dusung

\begin{tabular}{|c|c|c|c|}
\hline \multirow{2}{*}{ No } & \multirow{2}{*}{ Jenis } & \multicolumn{2}{|c|}{ Penggunaan Lahan/jumlah individu } \\
\hline & & Dusun & Non Dusun \\
\hline 1 & Belatung & 0 & 1 \\
\hline 2 & Lumbrikus & 19 & 9 \\
\hline 3 & Cacing garis & 0 & 1 \\
\hline 4 & Arachnida & 1 & 8 \\
\hline 5 & Insecta & 1 & 1 \\
\hline 6 & Myriapoda & 8 & 2 \\
\hline 7 & Parattrechina 1 & 1 & 5 \\
\hline 8 & Tetraponera 1 & 1 & 1 \\
\hline 9 & Tetraponera 2 & 1 & 2 \\
\hline 10 & Tetraponera 3 & 2 & 4 \\
\hline 11 & Parattrechina 2 & 4 & 24 \\
\hline 12 & Parattrechina 3 & 1 & 2 \\
\hline \multirow[t]{2}{*}{13} & Myriapoda & 2 & 1 \\
\hline & Total individu & 41 & 61 \\
\hline
\end{tabular}

Berdasarkan Tabel diketahui jumlah individu tertinggi adalah semut di areal non dusung dan cacing di areal dusung. Dominannya semut pada daerah non dusung dikarenakan sifat semut yang merupakan predator dan pemakan sisa-sisa tumbuhan. Wilayah non vegetasi atau berumput merupakan tempat strategis bagi semut untuk bersarang. Semut dapat menggali tanah sehingga menyebabkan terangkatnya nutrisi tanah. Cacing lebih dominan pada areal dusung dikarenakan memiliki kondisi iklim mikro yang sesuai bagi kelangsungan hidup cacing. Menurut Notohadiprawiro (1998) dalam Sugiyarto et al. (2007), makrofauna tanah lebih menyukai keadaan yang lembab dan masam lemah sampai netral.
Keberadaan fauna tanah sangat dipengaruhi oleh faktor lingkungan yaitu faktor biotik dan faktor abiotik. Faktor lingkungan abiotik yang mempengaruhi adalah faktor fisika antara lain tekstur tanah, struktur tanah, dan faktor kimia antara lain $\mathrm{pH}$, salinitas, kadar bahan organik dan unsur mineral tanah. Sedangkan faktor biotik yang mempengaruhi antara lain mikroflora dan tanaman. Tanaman dapat meningkatkan kelembaban tanah dan penghasil seresah yang disukai fauna tanah. Brussard (1998) dalam Nusroh (2007) menyatakan bahwa sisa tanaman dan pupuk organik merupakan bahan organik yang digunakan sebagai bahan makanan. Oleh karena itu, fauna tanah dapat ditemukan pada tanahtanah bervegetasi (Nusroh, 2007). 
Sugiyarto dkk (2007) dan Sayad dkk (2012) dalam Sazali 2015, menjelaskan makrofauna tanah berperan penting dalam dekomposisi bahan organik tanah guna menyediakan unsur hara. Makrofauna akan memecah menjadi lebih sederhana substansi nabati yang mati kemudian bahan tersebut dikeluarkan dalam bentuk kotoran yang kita kenal sebagai bahan humus. Bahan humus tersebut kemudian akan ditumbuhi oleh berbagai jenis mikroba yang melakukan konsorsium untuk menguraikan dengan bantuan enzim spesifik, sehingga terjadi proses dekomposisi bahan mineral yang bisa dimanfaatkan langsung oleh organisme lain (Whalen dan Hamel, 2004 dalam Sazali,2015).

\section{Analisis Vegetasi}

Hasil analisis vegetasi menunjukkan bahwa jenis, jumlah dan kerapatan lebih tinggi ditemukan pada dusung dibandingkan pada non dusung. Nilai luas bidang dasar pada areal dusung untuk tingkat pohon sebesar 5,333, pancang 0,381 lebih besar daripada non dusung sebesar 0,752 untuk pohon dan pancang sebesar 0,216 .
Nilai kerapatan pada areal dusung lebih tinggi dibandingkan pada areal non dusung baik untuk tingkat pohon, tiang, pancang maupun semai. Nilai frekuensi areal dusung untuk setiap tingkat lebih besar daripada non dusung.

Jenis-jenis vegetasi pada areal dusung meliputi Sagu (Metroxilon sagu), Coklat (Theobroma cacao), Kelapa (Cocus nucifera), Cengkih (Eugenia aromatica), Pala (Myristica fragrans), Durian (Durio zibetinus), Sirsak (Annona muricata), Langsat (Langsium domesticum), Manggis (Garcinia mangostana), Mangga (Mangifera spp), Kenari (Canarium sp), Rambutan (Nephelium lappaceum), Linggua (Pterocarpus indicus), Gofasa (Vitex gofasus), Pulai (Alstonia scholaris), Bua Rao(Dracontomelon dao dan Kayu Titi (Gmelina mollucana). Vegetasi penyusun non dusung didominasi Singkong (Manihot utilisima) pada tingkat semai, Pepaya (Carica papaya) pada tingkat sapihan, Linggua (Pterocarpus indicus) pada tingkat tiang dan Mangga (Mangifera sp) pada tingkat pohon. 
Tabel 6. Komposisi Vegetasi pada dusung dan non dusung

\begin{tabular}{cclcccccccc}
\hline No & $\begin{array}{c}\text { Penggunaan } \\
\text { Lahan }\end{array}$ & Tingkat & LBD & K & KR & F & FR & D & DR & INP \\
\hline 1 & Dusung & Pohon & 5,333 & 343,333 & 100 & 4,8 & 100 & 17,776 & 100 & 300 \\
& & Tiang & 0,381 & 1.573 & 100 & 4,6 & 100 & 5,075 & 100 & 300 \\
& & Pancang & & 6.133 & 100 & 3,8 & 100 & & & 200 \\
& & Semai & & 28.167 & 100 & 7,33 & 100 & & & 200 \\
\hline \multirow{2}{*}{2} & Non Dusung & Pohon & 0,752 & 186,667 & 100 & 3,13 & 100 & 2,508 & 100 & 300 \\
& & Tiang & 0,216 & 746,667 & 100 & 2,67 & 100 & 2,877 & 100 & 300 \\
& & Pancang & & $5.706,67$ & 100 & 2,93 & 100 & & & 200 \\
& & Semai & & $15.666,67$ & 100 & 7,13 & 100 & & & 200 \\
\hline
\end{tabular}

Keterangan : Data Olahan, 2018

Bahan Organik (C-organik)

Hasil analisis tanah untuk dilakukan di Laboratorium BPTP

Makassar seperti tertera pada Tabel 7.

mengetahui kandungan $\mathrm{C}$ organik yang

Tabel 7. Rata-rata C-Organik pada areal Dusung dan Non Dusung

\begin{tabular}{|c|c|c|c|c|c|}
\hline \multirow{2}{*}{$\begin{array}{l}\text { Waktu Pengukuran } \\
\text { (WIT) }\end{array}$} & \multirow[t]{2}{*}{$\begin{array}{l}\text { Pola } \\
\text { Agroforestry }\end{array}$} & \multicolumn{2}{|c|}{$\mathrm{C}$ organik (\%) } & \multirow[b]{2}{*}{ Jalur III } & \multirow{2}{*}{ Rata-rata } \\
\hline & & Jalur I & Jalur II & & \\
\hline \multirow[t]{2}{*}{ pagi (07.00-10.00) } & Dusung & 6,96 & 7,02 & 6,09 & 6,69 \\
\hline & Non Dusung & 4,64 & 5,02 & 4,9 & 4,85 \\
\hline \multirow[t]{2}{*}{ Siang (12.00-15.00) } & Dusung & 7 & 6,9 & 6,7 & 6,87 \\
\hline & Non Dusung & 4,55 & 4,56 & 4,89 & 4,67 \\
\hline \multirow[t]{4}{*}{ Sore (17.00-18.00) } & Dusung & 6,87 & 7,01 & 6,89 & 6,92 \\
\hline & Non Dusung & 4,56 & 4,54 & 5,12 & 4,74 \\
\hline & Dusung & 6,94 & 6,98 & 6,56 & 6,83 \\
\hline & Non Dusung & 4,58 & 4,71 & 4,97 & 4,75 \\
\hline
\end{tabular}

Ket.: $*$ Rata-rata Dusung, ${ }^{* *}=$ Rata-rata Non Dusung

Berdasarkan Tabel di atas rata-rata nilai $\mathrm{C}$ organik pada areal dusung lebih tinggi dibandingkan $\mathrm{C}$ organik pada areal non dusung dengan nilai masing-masing sebesar $6,83 \%$ dan $4,75 \%$. 


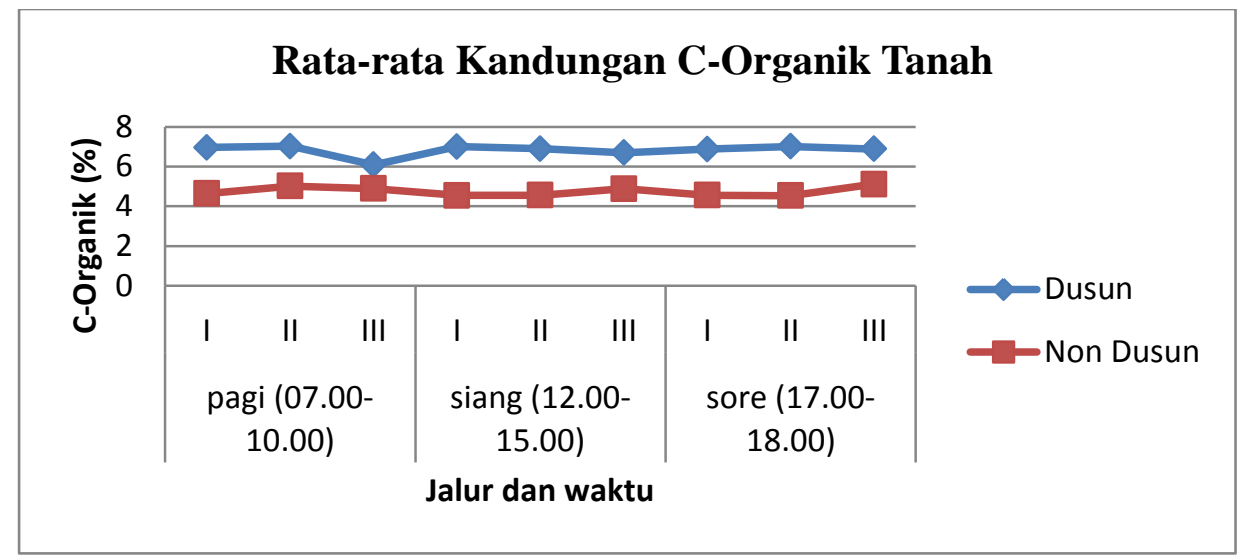

Gambar 9. Rata-rata C-Organik Tanah Dusung dan Non Dusung

Karbon (C) merupakan salah satu unsur yang mengalami daur dalam eosistem. Dimulai dari karbon yang ada di atmosfer berpindah melalui tumbuhan hijau (produsen), konsumen dan organisme pengurai, kemudian kembali ke atmosfer. Di atmosfer karbon terikat dalam bentuk senyawa karbondioksida $\left(\mathrm{CO}_{2}\right)$ (Indriyanto, 2015). Kebanyakan $\mathrm{CO}_{2}$ di udara dipergunakan oleh tanaman selama fotosintesis dan memasuki ekosistem melalui serasah tanaman yang jatuh dan akumulasi C dalam biomasa (tajuk) tanaman. Separuh dari jumlah $\mathrm{C}$ yang diserap dari udara bebas tersebut diangkut ke bagian akar berupa karbohidrat dan masuk ke dalam tanah melalui akar-akar yang mati (Hairiah, 2003).

Pengukuran neraca karbon (C) dilakukan pada beberapa macam pola tanam di Pakuan Ratu, yaitu pola berbasis ubikayu, budidaya pagar dan tumpang gilir tanaman leguminosa (kacang-kacangan). Hasilnya menunjukkan bahwa pola tanam berbasis ubi kayu memberikan neraca $\mathrm{C}$ negatif (artinya jumlah $\mathrm{C}$ yang terangkut keluar > jumlah C yang kembali ke tanah), dengan jumlah yang terangkut sekitar 7 ton ha-1 th-1 terutama terangkut sebagai umbi dan batang. Pola tanam budidaya pagar memberikan neraca $\mathrm{C}$ positif, di mana jumlah keluaran $\mathrm{C}$ yang terangkut panen sekitar 1.5 ton ha-1 th-1, dan masukan $\mathrm{C}$ sekitar 2.5 ton ha-1 th-1 sebagai biomas hasil pangkasan. Pola tanam tumpang gilir dengan tanaman kacang-kacangan penutup tanah menghasilkan kelebihan (surplus) masukan C ke dalam tanah sekitar 1.5 ton ha- 1 th-1 (Widianto dkk, 2013).

Pada setiap ekosistem jumlah karbon tersimpan berbeda-beda, hal ini disebabkan perbedaan keanekaragaman dan kompleksitas komponen yang menyusun ekosistem, sehingga dapat berpengaruh terhadap siklus karbon. Pada ekosistem dengan komunitas tumbuhannya sempurna dan keanekaragaman spesies 
tumbuhannya tinggi, maka produksi $\mathrm{CO}_{2}$ baik oleh akativitas organisme pengurai, proses respirasi, maupun penggunaan bahan bakar fosil akan diimbangi leh proses pengikatan/fiksasi $\mathrm{CO}_{2}$ oleh tumbuhan (Indriyanto, 2015).

\section{Analisis Uji Statistik}

Hasil uji t berpasangan untuk setiap parameter pada areal dusung disajikan pada Tabel 8.

\begin{tabular}{llccc} 
Tabel 8. Hasil Uji t Berpasangan pada Areal Dusung dan Non Dusung \\
\hline \multicolumn{1}{c}{ No } & \multicolumn{1}{c}{ Parameter } & T Hitung & $\begin{array}{c}\mathrm{P} \\
\text { Hitung }\end{array}$ & $\mathrm{T}_{0,05}$ Tabel \\
\hline 1 & $\mathrm{CO}_{2}$ & $-4,60$ & 0,002 & 1,8595 \\
2 & Suhu Udara & $-5,26$ & 0,001 & \\
3 & Kelembaban Udara & 0,27 & 0,793 & \\
4 & Suhu Tanah & $-5,2$ & 0,001 & \\
5 & Kelembaban Tanah & 1,36 & 0,211 & \\
6 & pH Tanah & 0,6 & 0,612 & \\
7 & Kadar Air Tanah & 8,47 & 0,014 & \\
8 & Makrofauna Tanah & $-0,71$ & 0,490 & \\
9 & Vegetasi & 1,01 & 0,389 & \\
10 & C-Organik & 14,69 & 0,000 & \\
\hline
\end{tabular}

Hasil uji berpasangan menunjukkan nilai $\mathrm{t}$ hitung yang lebih kecil dibandingkan dengan nilai $\mathrm{t}_{0,05}$ Tabel $(1,8331)$, hal ini menunjukkan bahwa parameter kelembaban udara, , $\mathrm{pH}$ tanah, makrofauna tanah dan vegetasi tidak berbeda nyata.

Nilai hasil uji t untuk parameter $\mathrm{CO}_{2}$ ,suhu udara, suhu tanah, kadar air tanah dan C-Organik. Nilai t hitung $\mathrm{CO}_{2}=-16,06$ ; suhu udara $=-5,11 ;$ suhu tanah $=-3,62$; kelembaban tanah $=2,16$, kadar air tanah $=8,47$, dan C-Organik $=8,53 ;$ nilai $\mathrm{t}$ hitung yang lebih besar dari nilai t Tabel dan nilai $\mathrm{p}<0,05$ yang menunjukkan bahwa ada beda nyata antara $\mathrm{CO}_{2}$, suhu udara, suhu tanah, kadar air tanah dan C-Organik pada areal dusun dan non dusun.

Hasil analisis korelasi antara parameter $\mathrm{CO}_{2}$ dengan suhu udara, kelembaban udara, suhu tanah, kelembaban tanah dan C-Organik pada areal dusung dan non dusung menunjukkan hasil yang berbeda seperti tersaji pada Tabel 9 dan 10. 
Tabel 9. Analisis Korelasi pada Areal Dusung

\begin{tabular}{|c|c|c|c|c|c|c|}
\hline \multirow{2}{*}{ No } & \multirow{2}{*}{ Parameter } & \multicolumn{5}{|c|}{$\mathrm{R}^{2} / \mathrm{P}$} \\
\hline & & $\mathrm{CO}_{2}$ & $\mathrm{~T}$ & $\mathrm{RH}$ & TT & RH Tanah \\
\hline \multirow{2}{*}{1} & \multirow{2}{*}{ Suhu Udara } & $0,282^{*}$ & & & & \\
\hline & & $0,463^{* *}$ & & & & \\
\hline \multirow[b]{2}{*}{2} & \multirow{2}{*}{ Kelembaban Udara } & $0,185^{*}$ & 0,316 & & & \\
\hline & & $0,634^{* *}$ & 0,408 & & & \\
\hline \multirow[b]{2}{*}{3} & \multirow{2}{*}{ Suhu Tanah } & 0,194 & 0,856 & 0,595 & & \\
\hline & & 0,617 & 0,003 & 0,091 & & \\
\hline \multirow{2}{*}{4} & \multirow{2}{*}{ Kelembaban Tanah } & 0,044 & 0,012 & 0,414 & 004 & \\
\hline & & 0,911 & 0,976 & 0,26 & 0,992 & \\
\hline \multirow{2}{*}{5} & \multirow{2}{*}{ C-Organik } & $-0,556$ & $-0,063$ & $-0,613$ & $-0,351$ & 0,086 \\
\hline & & 0,911 & 0,976 & 0,26 & 0,992 & 0,825 \\
\hline
\end{tabular}

Ket: $*$ nilai $\mathrm{R}^{2}, * *=$ nilai $\mathrm{P}$

Tabel 10. Analisis Korelasi pada Areal Non Dusung

\begin{tabular}{|c|c|c|c|c|c|c|}
\hline \multirow{2}{*}{ No } & \multirow{2}{*}{ Parameter } & \multicolumn{5}{|c|}{$\mathrm{R}^{2} / \mathrm{P}$} \\
\hline & & $\mathrm{CO}_{2}$ & $\mathrm{~T}$ & $\mathrm{RH}$ & TT & RH Tanah \\
\hline \multirow{2}{*}{1} & \multirow{2}{*}{ Suhu Udara } & $0,632^{*}$ & & & & \\
\hline & & $0,068^{* *}$ & & & & \\
\hline \multirow[b]{2}{*}{2} & \multirow{2}{*}{ Kelembaban Udara } & 0,551 & 0,802 & & & \\
\hline & & 0,124 & 0,009 & & & \\
\hline \multirow[b]{2}{*}{3} & \multirow{2}{*}{ Suhu Tanah } & 0,356 & 0,828 & 0,549 & & \\
\hline & & 0,346 & 0,006 & 0,126 & & \\
\hline \multirow{2}{*}{4} & \multirow{2}{*}{ Kelembaban Tanah } & 0,149 & $-0,224$ & 0,619 & 0,098 & \\
\hline & & 0,701 & 0,562 & 0,076 & 0,802 & \\
\hline \multirow{2}{*}{5} & \multirow{2}{*}{ C-Organik } & 0,132 & $-0,238$ & 0,13 & 0,6 & 0,121 \\
\hline & & 0,735 & 0,537 & 0,739 & 0,879 & 0,757 \\
\hline
\end{tabular}

Ket $: *$ nilai $\mathrm{R}^{2}, * *=$ nilai $\mathrm{P}$

\section{Peranan Pola Dusung dan Non Dusung}

Dusung di Desa Ureng mengkombinasikan tanaman tahunan (buah dan kayu) dan tanaman semusim (buah dan sayuran) serta tanam berumur panjang/perkebunan yang membentuk kanopi yang rapat. Kondisi iklim mikro di dalam dusun berbeda dengan kondisi iklim non dusung dimana kondisi ekologi dusung lebih baik. Dusung memberikan suhu udara maupun suhu tanah yang lebih rendah daripada non dusung serta kadar air tanah dan kandungan C-Organik yang lebih tinggi daripada non dusung.

Agroforestri memberikan kontribusi yang sangat penting terhadap jasa lingkungan (environmental services) antara lain mempertahankan fungsi hutan dalam mendukung DAS (daerah aliran sungai), mengurangi konsentrasi gas rumah kaca di atmosfer, dan mempertahankan keanekaragaman hayati. 
Mengingat besarnya peran Agroforestri dalam mempertahankan fungsi DAS dan pengurangan konsentrasi gas rumah kaca di atmosfer melalui penyerapan gas $\mathrm{CO}_{2}$ yang telah ada di atmosfer oleh tanaman dan mengakumulasikannya dalam bentuk biomasa tanaman, maka agroforestri sering dipakai sebagai salah satu contoh dari "Sistem Pertanian Sehat" (Hairiah dan Utami, 2002) dalam Widianto (2003). Demikian halnya dengan sistem agroforestri Dusung, jika dilihat dari hasil analisis parameter-parameter di atas. Untuk CO2 sesuai Tabel t test dapat dilihat nilai hasil $\mathrm{t}$ test yang negatif menunjukkan bahwa CO2 pada areal dusung lebih kecil jika dibandingkan dengan nilai $\mathrm{CO}_{2}$ pada areal non dusung. Demikian halnya dengan parameter-parameter yang lain.

Sejalan dengan hal di atas, sistem agroforestri dusung juga mampu mempertahankan sifat-sifat fisik lapisan tanah atas jika dilihat dari nilai C-Organik yang lebih tinggi dibandingkan nilai $\mathrm{C}$ Organik pada areal non dusung.

\section{KESIMPULAN DAN SARAN}

\section{Kesimpulan}

1. Dusung adalah pola bercocok tanam tradisional asli Maluku yang memadukan tanaman tahunan, tanaman pertanian berumur pendek, buah-buahan dan sayuran. Non Dusung adalah areal kebun atau bekas kebun
Sistem multistrata (agroforestri) dengan pohon naungan atau pelindung merupakan sistem konservasi yang sangat baik (Agus et al., 2002) dalam Mulyoutami et all (2003). Lapisan tajuk pada sistem multistrata yang menyerupai hutan dapat memberikan fungsi konservasi yang baik dalam mengurangi tingkat erosi tanah. Selain itu, melalui lapisan tajuk, sinar matahari tidak berpengaruh langsu ng terhadap kopi sehingga kelembaban udara pada kebun kopi dapat terjaga. Tanaman pelindung juga dapat membantu meningkatkan kesuburan tanah (Mulyoutami et all, 2003). Kondisi ini sama seperti pada areal dusung yang dapat dilihat dari nilai-nilai $t$ hitung dari parameter suhu udara, suhu tanah, kadar air tanah dan C-Organik. Dari hasil analisis diketahui bahwa dusung lebih baik perannya dalam konservasi lingkungan jika dibandingkan dengan non dusung yang ditunjukkan oleh nilai suhu udara, suhu tanah, kadar air tanah dan kandungan C-organik.

yang tidak diklaim petani sebagai dusung dan kondisi lahan terbuka, terdiri semak belukar, atau usaha kebun yang bersifat sementara

2. Nilai rata-rata $\mathrm{CO}_{2}$ terendah pada dusung sebesar 468,72 ppm dan non dusung sebesar 474,91 ppm, suhu 
3. udara rata-rata pada dusung sebesar $28,56^{\circ} \mathrm{C}$, dan pada areal non dusung rata-rata suhu udara sebesar $29,52^{\circ} \mathrm{C}$. Kelembaban udara sebesar $81,18 \%$ dan non dusung sebesar $80,31 \%$. Suhu tanah tertinggi pada non dusung sebesar $27,67^{\circ} \mathrm{C}$ dan terendah pada dusung sebesar $25^{\circ} \mathrm{C}$. Kelembaban tanah pada dusung sebesar $82,27 \%$ dan pada non dusung sebesar $81,25 \%, \mathrm{pH}$ tanah pada dusung sebesar 4,15 dan non dusung sebesar 4,02. Kadar air tanah tertinggi pada dusung sebesar $44,273 \%$ dan non dusung sebesar $32,847 \%$. Makrofauna tanah menunjukkan jumlah jenis dan individu tertinggi pada areal non dusung sebesar 13 jenis dan 61 individu, dan areal dusung sebesar 11 jenis dan 41 individu. Kerapatan vegetasi tertinggi ada pada tingkat semai dusung sebesar 28.176 dan pada tingkat semai non dusung sebesar 15.667. Kandungan C-Organik

\section{DAFTAR PUSTAKA}

Ardiansa, 2010. Analisis Skala Usaha Tani Pola Agroforestry Di Desa Leko Pancing Kecamatan Tanralili Kabupaten Maros. Tesis PascaSarjana Universitas Hasannudin, Makassar.

Budiarti dkk, Pengaruh Tata Hijau Terhadap Suhu dan Kelembaban Relatif Udar, Pada Balai Besar Pengembangan Mekanisasi Pertanian, Serpong. tertinggi pada dusung sebesar $6,83 \%$ dan non dusung sebesar $4,75 \%$.

4. Hasil uji $\mathrm{t}$ menunjukkan bahwa ada kesamaan antara dusung dan non dusung untuk parameter $\mathrm{CO}_{2}$, kelembaban udara, kelembaban tanah, $\mathrm{pH}$ tanah, makrofauna tanah dan vegetasi, sedangkan berbeda pada suhu udara, suhu tanah, kadar air tanah, makrofauna tanah dan COrganik jika dilihat dari nilai t hitung.

5. Peranan dusung terhadap konservasi lingkungan di Desa Ureng lebih baik jika dibandingkan dengan non dusung yang ditunjukkan oleh nilai suhu udara, suhu tanah, kadar air tanah dan kandungan C-organik.

\section{Saran}

Perlu penelitian lebih lanjut mengenai pengukuran unsur-unsur iklim pada kondisi yang lebih bervariasi sistem pemanfaatan lahannya sehingga informasi yang didapatkan lebih lengkap.

Bulan R., 2010. Kajian Potensi Jasa Lingkungan (Biomassa dan Karbon) Hutan Mangrove di Tanjung Bara, Sangatta Utara, Kalimantan Timur. Sekolah Pascasarjana, Institut Pertanian Bogor, Bogor.

Hairiah dkk, 2003. Bahan Ajar 6, Neraca Hara dan Karbon Dalam sistem Agroforestri. World Agroforestry Centre- ICRAF SE Asia, PO.BOX 161, Bogor, 16001 
Hanafiah dkk, 2014.. Biologi Tanah, Ekologi dan Mikrobiologi Tanah. Rajawali Pers, Jakarta.

Hasanah dkk, 2014. Petunjuk Praktikum Ekologi Tumbuhan, "Pengukuran Suhu, Kelembaban Udara, Tanah dan $\mathrm{pH}$ Tanah Serta Kadar Air dan C Organik Tanah". Laboratorium Biologi Universitas Muhammadiyah Malang.

Hatulesilla Y. W., 2009. Alih Fungsi Lahan Dan Alternatif Konservasi Lahan "Sistem Dusung, Jurnal Agroforestri Volume IV Nomor 1 Maret 2009, 34-40.

Irawan A., 2009. Hubungan Iklim Mikro Dan Bahan Organik Tanah Dengan Emisi Co2 Dari Permukaan Tanah (Studi Kasus Hutan Alam Babahaleka Taman Nasional Lore Lindu, Sulawesi Tengah). Skripsi Institut Pertanian Bogor.

Isbeanny J, Fauzia R., 2014. Makro Fauna Tanah. Fakultas Sains dan Teknologi, Universitas Islam Negeri Syarif Hidayatullah Jakarta.
Juliansyah A.,2016. Keanekaragaman Makrofauna Tanah pada Berbagai Tipe Tegakan di Areal Hutan Tanaman RPH Pandantoyo, KPH Kediri. Skripsi. Departemen Silvikultur Fakultas Kehutanan Institut Pertanian Bogor, Bogor.

Latumahina, 2016. Respon Semut Terhadap Kerusakan Antropogenik Pada Hutan Lindung Sirimau, Ambon. Jurnal Agrologia, Vol. 5, No.2, Oktober

Matinahoru J. M., 2014. A Review on Dusun as an Indigenous Agroforestry System Practiced in Small Islands. Occasional Papers No.54 (December 2014), 1-7.

Mulyoutami et all, 2003. Pengetahuan Lokal Petani dan Inovasi Ekologi Dalam Konservasi dan Pengolahan Tanahpada Pertanian Berbasis Kopi di Sumberjaya, Lampung Barat. World Agroforestry Center-ICRAF, Bogor.

Nusroh Z, 2007. Studi Diversitas Makrofauna Tanah Di Bawah Beberapa Tanaman Palawija Yang Berbeda di Lahan Kering Pada Saat Musim Penghujan. Fakultas Pertanian Universitas Sebelas Maret Surakarta. 